\title{
Giyah Supanggah: Trace of Artist of Wayang Topeng Dalang Klaten
}

\section{\& THEATREREVIEW}

jurnal tari, teater, dan wayang

volume 1 number 2 ,

November 2018

page $96-105$

\author{
Sri Dwi Wahyuni \& Hersapandi ${ }^{1}$ \\ Dance Department, Institut Seni Indonesia Yogyakarta
}

\begin{abstract}
The significance of this research is the transmission of cultural tradition art from the descendants of Makaton (Somokaton) puppeteers, namely Jaka Purwa Pandaya (father) and Widhi Harsono (grandfather). As an active heir, Giyah Supanggah is a woman who becomes a puppeteer as well as dancer of wayang topeng dalang, cut and make puppets, and deepen the knowledge and skills of playing gamelan. Giyah is a figure of artist who has various artistic talents and emancipation figure of Javanese women of her times. As a mask puppet dancer, she is committed to preserving and developing the genre of performing arts in order to survive and thrive. Giyah's integrity is shown in the art activities by establishing Sanggar Sekar Kedhaton in her home. It is expected that the transmission of culture among the younger generation as the successor of traditional art can take place. The present study belongs to a qualitative research employing descriptive-analysis based on anthropological approach. It focuses on the analysis of internalization process, socialization, and enculturation that form Giyah as an active heir of puppeteer and dancer of wayang topeng dalang from Klaten. The qualification of Giyah as a puppeteer and dancer contributes to the preservation of traditional art marked by her reputation as a public figure of a traditional artist. The purpose of this study is to know and describe the role of Giyah as a bearer of traditional art as a legacy of local wisdom. The benefit is to reveal the existence of a forum of creativity for the younger generation in an effort to preserve and develop the art of tradition in order not to be extinct faded by the times.
\end{abstract}

Keywords: Giyah Supanggah; female puppeteer; wayang topeng dalang

\begin{abstract}
Abstrak
Signifikansi penelitian ini adalah transmisi seni tradisi yang bersifat kultural dari keluarga keturunan dalang Makaton (Somokaton), yakni Jaka Purwa Pandaya (ayah) dan Widhi Harsono (kakek). Sebagai pewaris aktif, Giyah Supanggah adalah perempuan yang menjadi dalang wayang kulit dan penari wayang topeng dalang, menatah dan menyungging wayang kulit, yang mendalami pengetahuan dan keterampilan bermain gamelan. Giyah adalah sosok seniman yang mempunyai berbagai talenta seni dan tokoh emansipasi wanita Jawa di zamannya. Sebagai penari wayang topeng dalang, ia memiliki komitmen untuk melestarikan dan mengembangkan genre seni pertunjukan ini agar tetap hidup dan berkembang. Integritas Giyah ditunjukkan dalam kegiatan berkesenian dengan mendirikan Sanggar Sekar Kedhaton di rumahnya, sehingga diharapkan terjadi transmisi budaya di kalangan generasi muda sebagai penerus seni tradisi. Penelitian kualitatif yang bersifat deskriptif-analisis dengan pendekatan antropologi difokuskan pada analisis proses internalisasi, sosialisasi, dan enkulturasi yang membentuk Giyah sebagai pewaris aktif dalang
\end{abstract}

Correspondence: Dance Department, Institut Seni Indonesia Yogyakarta. Jln. Parangtritis KM 6,5 Sewon, Yogyakarta. E-mail: seikuan@yahoo.co.id. HP.: +6285959011241 
dan wayang topeng dalang Klaten. Kualifikasi Giyah sebagai dalang dan penari wayang topeng dalang perempuan memberi kontribusi terhadap pelestarian seni tradisi yang ditandai reputasi dirinya sebagai figur publik seniman seni tradisi. Tujuan penelitian ini adalah ingin mengetahui dan mendeskripsikan peran Giyah sebagai pengemban seni tradisi sebagai warisan kearifan lokal. Manfaatnya adalah mengungkapkan adanya wadah kreativitas bagi generasi muda dalam upaya melestarikan dan mengembangkan seni tradisi agar tidak punah ditelan zaman.

Kata kunci: Giyah Supanggah; dalang perempuan; wayang topeng dalang

\section{Introduction}

Giyah Supanggah is the active heir of puppeteer and dancer from a puppeteer family of Makaton (Somokaton), namely Jaka Purwa Pandaya (father) and Widhi Harsono (grandfather). She is a versatile artist, as a puppeteer and dancer, sinden (singer) and pengrawit (music player) and a maker or producer of puppets. Giyah's life has been sustained by her profession as a puppeteer of wayang kulit purwa and dancer of wayang topeng dalang and the predicate of traditional art artist is passed down to her four children. It shows that the profession of puppeteers and artists of traditional arts can be used as financial support for her family. In the effort to support the performance of the show, she formed an art organization called Sekar Kedhaton in Kadipolo, Keputran Village, Kemalang Sub-district, Klaten District.

Cultural inheritance system, which is inherited to the grandchildren, is a form of transmission of knowledge and skills in large environments. A cultural artist tends to make his son or grandchild an artist. His son or grandson is culturally following in the footsteps of his father or grandfather to be an artist, namely continuing his family artistry skills (Hairus Salim and Dhian Hapsari, 2007: 9). It indicates that the role of the family is so important in the building of the personality of the descendants, that of being an active heir of the art expertise of the family and ancestors.

For Giyah, inheritance of art within herself is based on her individual consciousness by following the performances by her father and grandfather. Her father and grandfather play an important role in forming her character during her growth as a traditional artist. Her hard work, patience, and self-training, eventually formed Giyah as a traditional artist who becomes a model for her family and environment. On various occasions, Giyah always carries puppets of Klaten called wayang topeng dalang. For example, in 2014 at the Panji Mask Festival held at Taman Budaya Yogyakarta, she performed wayang topeng dalang as the representation from Klaten. In the show, Klaten contingent featuring Giyah figure was supported by a big family of puppeteer Somokaton.

The dynamics of the development of wayang topeng from Klaten is predominantly dominated by puppeteers who still have family ties (breeds). The family bond known as this breed is an internal factor affecting the lives of the dalang artists as the main actor or dancer in show (Bening Tri Suwasono, 2013: 350). The traditional art heritage that lasts for many years is a form of transmission of skills and knowledge supported by cultural inheritance systems. The phenomenon of cultural inheritance in Giyah Supanggah is a form of transmission within the family that allows Giyah Supanggah to learn continuously and socialize the knowledge and skill to the community around and outside the environment. Cultural learning process in outline can take place through three stages, namely internalization, socialization, and inculturation (Koentjaraningrat 1986: 228234).

The problem found in this study is how Giyah Supanggah as an active heir, received the inheritance of wayang topeng dalang 
dance in Klaten style and how how Giyah maintains the style (of Klaten). The purpose and significance of the study is to describe Giyah's life in accepting the art inheritance, thus, it can be seen how she tries to maintain wayang topeng dalang as a masterpiece of Klaten. This research employs a biographical approach that is part of the writing of history in social facts because the biography also explains the problems of a local culture, both tradition and the concept of life in general. That is to explain the life of someone who has an important role for the sustainability of the work or ideas that can be useful for the society in the explanation widely. According to Edel (Kutha Ratna, 2010: 380), writing a biography is the same as writing life.

Koentjaraningrat (1981: 197) suggests that the history of life is the individual experience, the biography of the subject of the creator under investigation. Life history not only contains live notes experienced by a character, but this approach is able to penetrate the social construction of a person's experience that can describe the social reality within the environment. The approach of cultural history in historical methodology is conceptualized as patterns of behavior, action, mind, various aspects of daily life which are cultural dimensions, always present in civilized society. To support biographical research, anthropological approach is also used, especially the dynamic learning process of culture, namely internalization, socialization, and enculturation.

\section{The History of Giyah and Her Family Background}

According to Kartodirdjo (1992: 60-61), the biography of the characters is told in chronological order from beginning to end; in a group of facts there needs to be determined the existence of a causal fact - cause (fact) - facts of effect; descriptive-narrative descriptions which requires a serialization process (sorting events); to give structure to the time there needs period making on episodes. Anthropological approach reveals the values that underlie the behavior of historical figures, status and lifestyle, belief system underlying the pattern of life, and so forth. The form of presentation of wayang topeng dalang as selfactualization of artist is a form of creative expression which underlies the presence of traditional art inheritance system.

Giyah was born in Manjung (also the birthplace of her mother Ngatijah), Puluh Watu, Ngawen, Klaten, precisely on August 8, 1967. In the process of sustainable living, the family is an important factor for the growth and formation of the child's personality. Giyah's father is Jaka Purwa Pandaya, the son of a wayang kulit puppeteer. Her mother, Ngatijah, comes from the region of Manjung, Ngawen, Klaten. Ngatijah was well known as a female dalang as well as a dancer. She often played Cakilan, until well known as PrahmenCakil, a cakil dancer. Joko Purwa Pandaya and Ngatijah have six children, namely (1) Giyah Supanggah (whose husband is a dalang), (2)

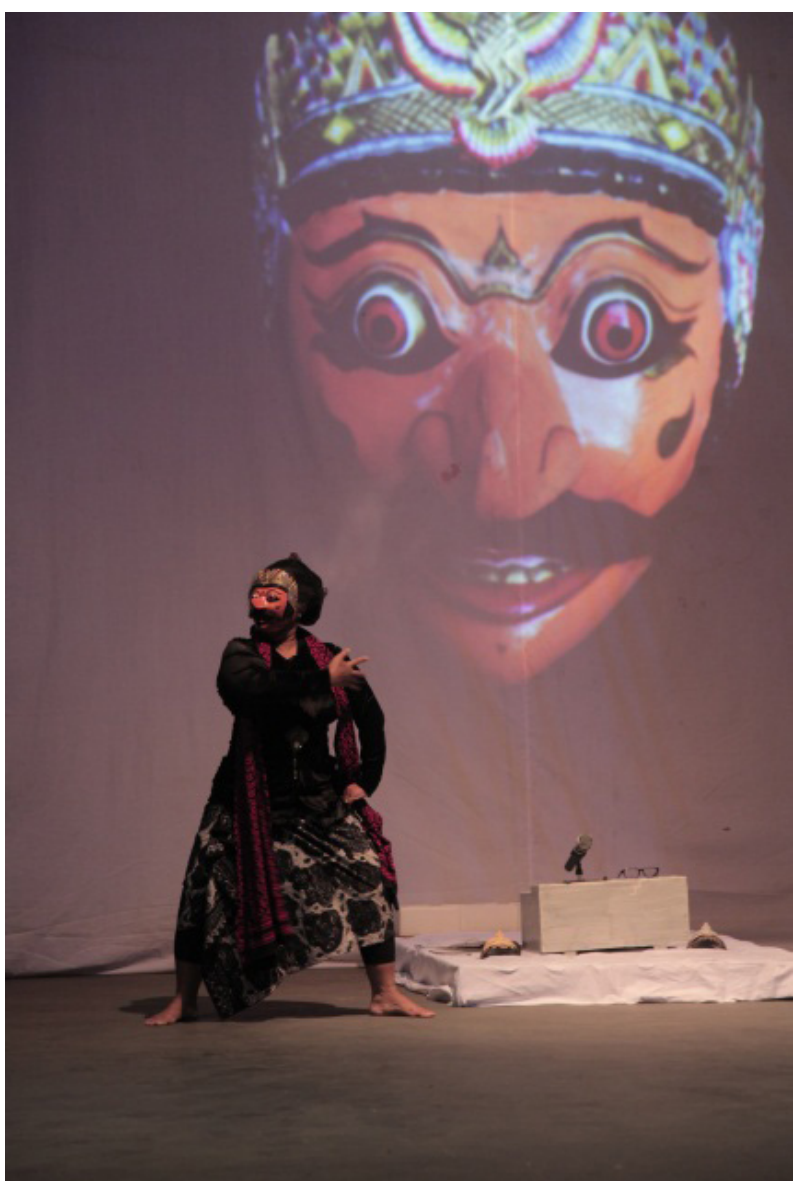

Figure 1. Giyah Supanggah dancing Klana on "Mawas Diri” performances at Jogja National Museum. (Photo: Renove, 2017) 
Ninik Sunarni, (3) Suyatmi (whose husband is also a dalang), (4) Muryanti (good at playing rebab), (5) Darsih, and (6) Slamet Wardono.

Giyah, as an active heir of his parents and ancestors, seeks to improve the mastery of knowledge and technical skills of being a puppeteer and dancer. The effort is done in the hope that local wisdom is preserved and then inherited by the next generation. From his marriage with Sartono, Giyah has descendants who inherit her artistry skills. Sri Eko Widodo, her eldest son, is a pengrawit (musical player for wayang) and a lecturer in Karawitan Department, Indonesian Institute of Arts Surakarta. He also can play as a puppeter but he prefers focusing on karawitan. Giyah's daughters, Sujar Krisna Widiyanto and Kasih Haryono are both dalang, and the other one, Luri Anggrahini, is a dancer.

Giyah is the eldest child of Joko Purwa Pandaya and Ngatijah. Ngatijah is famous as a female dalang as well as a dancer. She often played Cakilan, until famous as Cakil dancer. Giyah was born, lived, and raised in the environment of art tradition, so that the artistic activity shaped her as the active heir of dalang artist and dancer. Giyah has ascribed status, which means direct descendant of dalang artist and wayang topeng dalang, and at the same she has also achieved status as

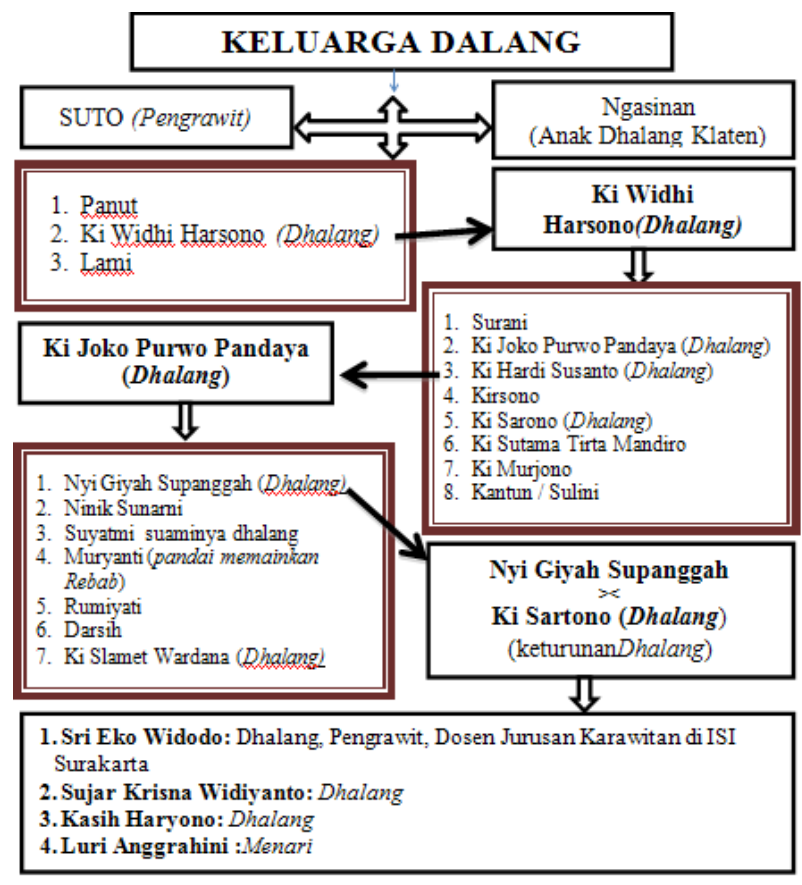

Figure 2. Genealogy of Giyah having to struggle to get qualified versatile artist, that is as puppeteer and dancer. Below this genealogy Giyah as descendant of the dalang of Klaten. Giyah is the eldest child of Joko Purwa Pandaya and Ngatijah. Ngatijah is famous as a female dalang as well as a dancer. She often played Cakilan, until famous as Cakil dancer. Giyah was born, lived, and raised in the environment of art tradition, so that the artistic activity shaped her as the active heir of dalang artist and dancer. Giyah has ascribed status, which means direct descendant of dalang artist and wayang topeng dalang, and at the same she has also achieved status as having to struggle to get qualified versatile artist, that is as puppeteer and dancer. Below this genealogy Giyah as descendant of the dalang of Klaten.

\section{Rituals and Beliefs}

Ritual is the social side of religion. If religion is defined as a system of understanding of the supernatural and sacred associated with life after death, rituals are the various social processes that give concrete form to the understanding of religion. Rituals are also interpreted as various public events that are bound by the rules, which in one way or another making thematic of the relation between the worldly realm and the spiritual realm (Hylland Eriksen, 1998: 365). Ritual event in its implementation always uses the arts as a ceremonial medium. According to William A. Haviland (1985: 224), art is a kind of product of human behavior that specifically uses the creative imagination to help human beings explain, understand, and enjoy life, that is art as a medium of ritual ceremony. It is believed by society that the integration between art, ritual and belief is part of the form of community empowerment in maintaining its communal spirit. Normative impression is in line with the normative culture, which is toward the realization of human values. These values are universal and binding to every human being. Rituals are not only a means of strengthening the group's social ties and reducing tension, but also a way to celebrate 
important events and cause crises, such as death, in order for the people concerned to be lighter to suffer. In traditional societies, usually unreasonable events end with a ritual performance, such as a wayang kulit or wayang topeng dalang.

Usually, the dalang always takes home some of the offerings to be shared with all the performers. Figure 4 is example of the offering in a wayang kulit show.

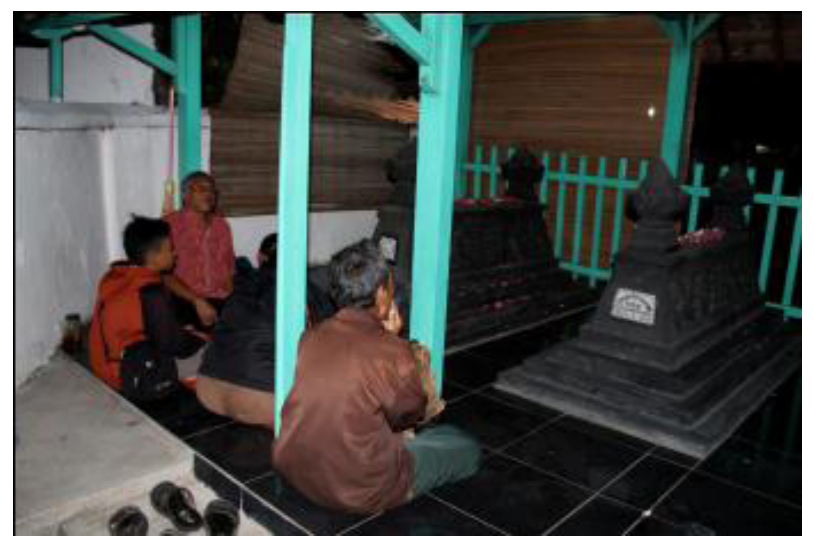

Figure 3. Pilgrimage at the Grave of Mbah Gondho Tukas, Topeng Klana Dancer and Wayang Topeng Dalang Klaten, in Manjung, Ngawen, Klaten. (Photo: Sri Dwi Wahyuni, 2017)

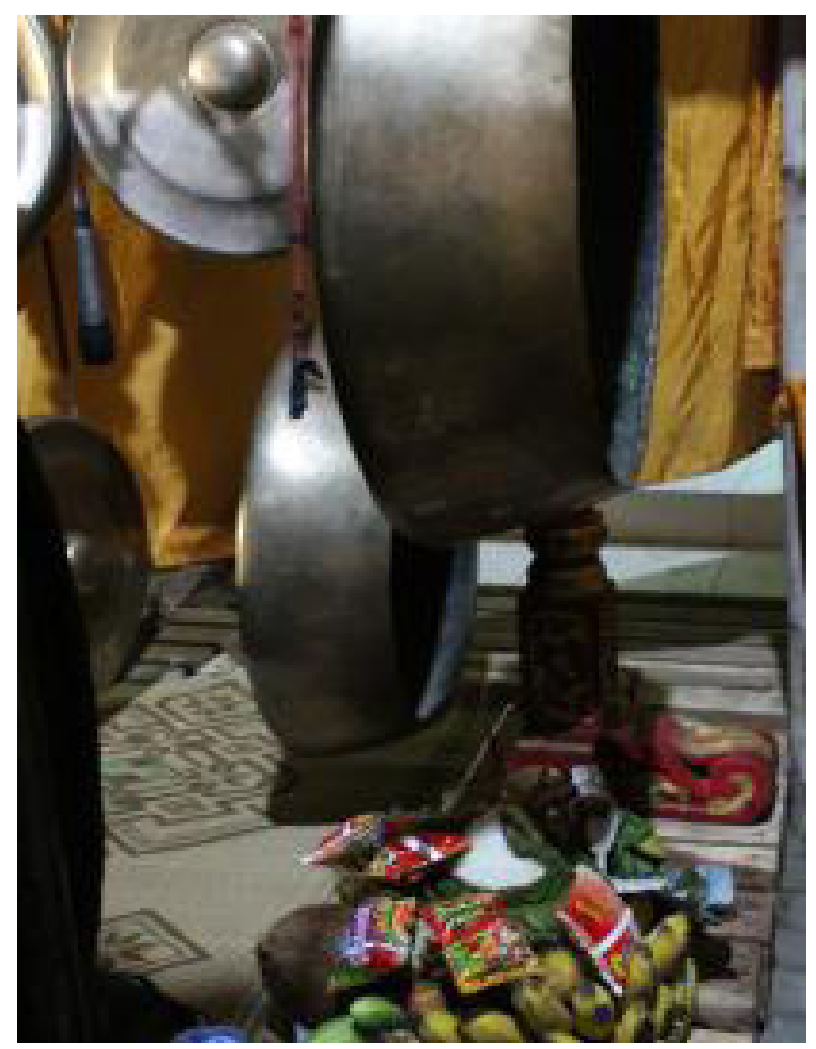

Figure 4. The offerings when performing at Pucangan, Bendan, Manisrenggo, Klaten, 20 September 2017. (Photo: Sri Dwi Wahyuni, 2017)

\section{Giyah and Her Educational Background}

Giyah grew up in Cleput, Somokaton. The little Giyah was raised by someone named Sarmin. Through learning directly from both parents, she has the ability to be a puppeteer as well as player of wayang topeng dalang. The popularity of Giyah as a puppeteer and player is unquestionable; even both types of traditional performances are the strength of the Giyah's appeal as the female dalang of her times. She founded an art gallery as a medium of inheritance and an informal education of traditional arts. Unlike her, her siblings can continue higher education, ranging from high school up to college.

In the context of performing or playing wayang topeng dalang, certainly it can not be separated by the demands of economic needs of the artists, so that the constituent factors in the stage is an important factor in maintaining the continuity of family life. For little Giyah, following her father or grandfather's shows is the process of enculturation and internalization of personality formation. For her, as a puppeteer and puppet mask dancer, the role of the cultural environment is an important factor in maintaining the creative community.

\section{Giyah as A Dalang and Player of Wayang Topeng Dalang}

Wayang topeng dalang is a kind of dramatari-shaped show of dialogue of prose and song whose story takes the epos of Panji. It is called wayang topeng dalang because the players are mostly from puppeteers of wayang kulit. According to oral tradition, the presence of wayang topeng dalang is based on two reasons. First, the event occurred first when the puppeteer was not on a show, that is, there is no wayang show yet. Secondly, there is a season of famine due to the dry season or the failure of the farmer's harvest, so the puppeteers make a show, namely mbarang topeng ${ }^{2}$. The tradition art of wayang topeng dalang of Klaten is one of the types of wayang topeng that grows and develops in Central Java. 
In the wayang topeng dalang show, Giyah, in addition to playing dashing figures, is also able to portray mbok Rondho-a widow who became the mother of Kleting Kuning (Dewi Candrakirana) and Kleting Abang who has envy and evil personality. In the entourage, Giyah is the only woman involved as a dancer so it is natural that she always plays mbok Rondho character. In the era before Giyah became a mask puppet dancer, the role of mbok Rondho was usually played by men who dressed up like women because the presence of women is considered taboo and inappropriate for mbarang. Therefore, the presence of Giyah as a mask dancer who plays the female character is an important part of the development of wayang topeng dalang. The inheritance or transmission of regeneration changes between men and women is an important part of the spirit of the time, allowing the emergence of female characters, such as Giyah, into to the puppetry art.

\section{Family, Environment, and Society}

In the management of the puppetry art, the position of the puppeteer or dalang is strategic and central, namely as a respected figure as a leader, so that the applied management system depends on him or her. The dalang manages the pengrawit (music players), pesinden (singers), peniti (assistant of dalang) including the payroll system. In many cases, having a show is often not accompanied by how much the contract should be paid so that each member is also uncertain about the amount of money received. Typically, the

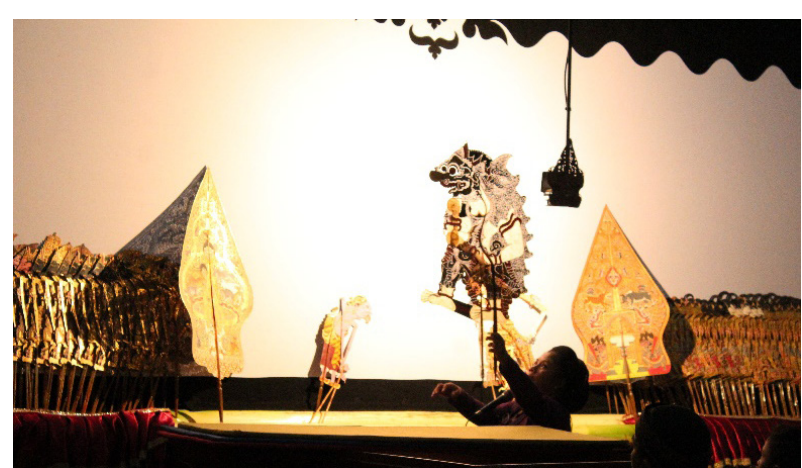

Figure 5. Giyah Supanggah at the 3rd World Wayang Day Festival ISI Surakarta, November 10, 2017. (Photo: Sri Dwi Wahyuni, 2017) division of honorarium is done at the place of celebration or place of performance and the amount of honor depends on the burden of each task that is done during one night.

Giyah never determines a certain tariff because it will be difficult if a puppeteer has a fixed rate. The public will be afraid to assume if a puppeteer or artist is not flexible on the rate matter. The understanding of Javanese who used the term to ask for help in a celebration or celebration activity gave the dalang's willingness not to ask for a certain fee, but it was left entirely to the person who had intentions so often the dalang asked all his supporters not to demand a big fee. There is also a case when a customer asks for the willingness of a puppeteer to conduct a show; one can perceive the wayang to please oneself and also to align him. Giyah cannot refuse if anyone asks for help in such a way. In bersih desa ritual event, people already have known the price (honorarium). They already know the usual tariff, or the range of money given to Giyah and her group.

The dedication of Giyah and Sartono (her husband) in society is undoubted, both on the wayang kulit and wayang topeng dalang as well as informal educational activities involving the community to learn the art of tradition as local wisdom. Thus, the life of wayang kulit and wayang topeng dalang still survive because of the direct support of the community. The communal spirit that is built eventually has a positive impact on the preservation and development of traditional art whose area is known as the area of artists. That becomes a pride of Kabenetan Klaten, Central Java.

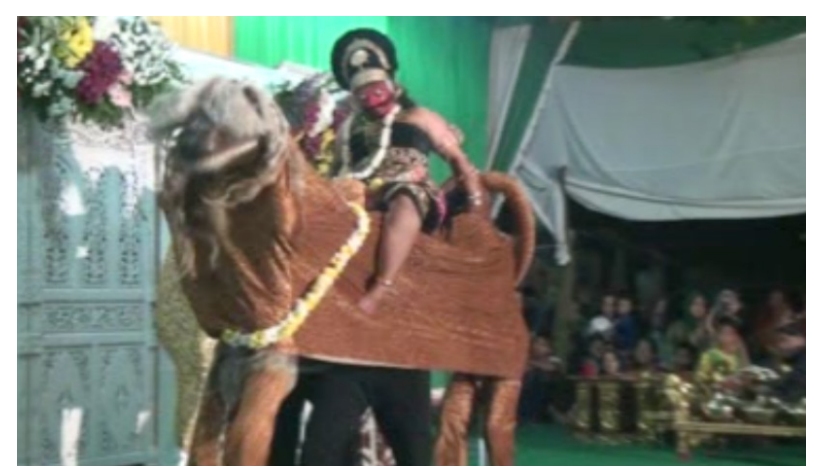

Figure 6. Video screenshot of Ketoprak Mataram Lintang Rinonce Renggani Pulung Sari, dated November 6, 2016. (Doc.: Giyah Supanggah, 2016) 


\section{Sekar Kedhaton Studio}

Sekar Kedhaton, founded by Giyah in 2003 , is one of his strategies to invite the surrounding environment to practice the arts, both puppetries as well as wayang topeng dalang. The art organization is equipped with complete gamelan, puppets, and wayang topeng dalang. Giyah cooperated with SD Kemalang in neraby to introduce art early to elementary school students. Gamelan learning and teaching activities are held every Monday, Tuesday, and Wednesday in the afternoon after school. In addition to inviting elementary students, Giyah also invites residents around to practice. The activity is done at night after the time of Isha prayer. In June, ahead of the Independence Day of the Republic of Indonesia, Sekar Kedhaton is crowded with local people for joining exercises, such as ketoprak, srandul, sruntul, and dances.

Sekar Kedhaton is actually a place of informal education for Giyah's children and the society around. Her third son named Kasih Haryono, while still in the $3^{\text {rd }}$ grade of Kemalang Junior High School, Klaten, cultivated karawitan and puppeteer in Klaten. His achievement is clearly shown in some competitions of macapat, sesorah, and puppeteer is on district as well as province levels. His accomplishment is supported by Giyah and the family so that the school and the family has become the inspiration for other children.

\section{Cultural Inheritance}

Culture is the whole system of ideas, actions, and the work of human beings in the framework of human life that belongs to the human self by learning (Koentjaraningrat, 1985: 180). In the context of human life, culture refers to various aspects of life, the ways of prevailing, the beliefs and attitudes, as well as the outcomes of the typical human activities for a particular society or population. According to Clifford Geertz (Irwan Abdullah, 2006: $1)$, culture is a pattern of meanings or meanings that are entirely interwoven in symbols and transmitted historically. It is further ex- plained that culture is a system of conceptions inherited in symbolic form, in which way man can communicate, preserve, and develop his knowledge and attitude toward life.

Cultural inheritance is a process of transitioning the values and norms that are carried out and passed on by the older generation to the younger generation with the aim of introducing values, norms and customs in life, the creation of orderly life, and harmonious conditions in society as a consideration that human life is short. Cultural inheritance can be equated with the term cultural transmission, which is an attempt to convey some knowledge or experience to be a principle in continuing the cultural relay, especially the best-regarded values that have become the standard guidelines in society.

The inheritance of traditional art, usually derived orally, is generally given by father to his sons. In addition to the knowledge and skills that must be mastered by them, such as the story, gending accompaniment, suluk, and performance techniques, there is also a lot of magical knowledge involved in it, called pedhalangan, the science or puppeteer art (van Groenendael, 1987: 6).

As a descendant of traditional art family, Giyah is able to absorb puppetry skills given by her father and grandfather so that the dalang profession and wayang topeng player manages to make herself as a quality tradition artist. The process of forming her personality as a puppeteer as well as a player is a cultural inheritance that puts the woman in fact able to become an active heir individual who is

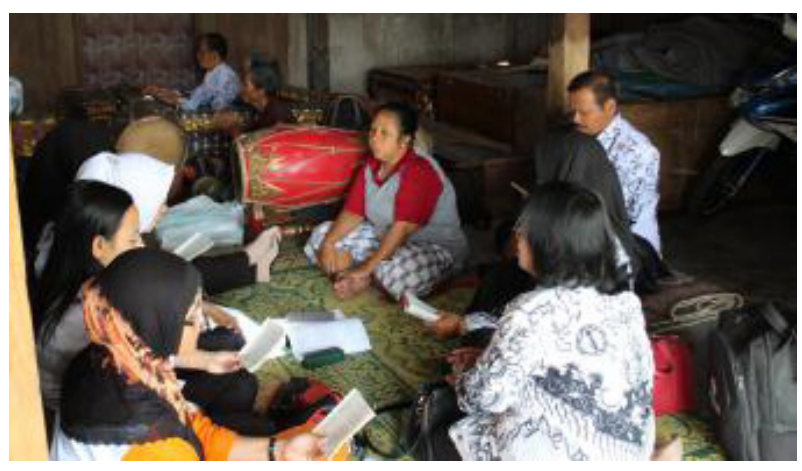

Figure 7. Giyah Supanggah trained female sinden (singers) of Junior High School 1 Kemalang, Klaten in Sekar Kedathon Studio.

(Photo: Sri Dwi Wahyuni, 2017) 
qualified in the field of expertise. According to Koentjaraningrat (1985: 228), the concept of the shift of society and culture in the context of the process of learning culture itself is largely formed by three processes, namely internalization, socialization, and enculturation.

\section{Cultural Internalization}

Cultural internalization is a long process since an individual is born until he or she dies. In the process he learns to instill all the feelings, desires, passions, and emotions that are necessary throughout his life on his personality. The process of internalizing the culture of Giyah as descendant of puppeteer and dancer is formed from childhood by following her father and grandfather's performances. In addition, she studied independently at home to master the knowledge and skills of dalang as well as player. As a dalang who gains qualified status, she is an individual who has integrity and commitment to become a professional artist of quality and professional. The nature of good desires is shown by how she associates with family members, fellow artists, and society. In survival, she believes that through art, her family can survive while maintaining its integrity and commitment as a professional artist. Giyah devote herself to her family and profession in the hope that the world of beauty in wayang kulit and wayang topeng dalang remains alive as well as develops as local wisdom and provides entertainment to the community.

Giyah's self-internalization is largely determined by the input and advice of the parents when she is on stage, either as a puppet artist or wayang topeng dalang artist. This has built Giyah's maturity as an artist. In addition to learning in practice, she also learned to deepen the knowledge by reading the script puppet written by Joko Purwa Pandaya. Wayang script and wayang topeng dalang are the sources of story that help in developing the scenario of the plays, both wayang and wayang topeng dalang. In any discussion with her parents, she usually asks to practice first what has been learned.
It is intended that if there are shortcomings, they can be directly given suggestions and improved. After staging her father always gives a personal evaluation at home.

The process of socialization is related to the process of learning culture in relation to social systems. In the process of socializing an individual from childhood to his old age learns patterns of action in interaction with all kinds of individuals around him who occupy different social roles (Koentjaraningrat, 1985: 229). The pattern of action is the way of action created to be imitated by many people. A way of acting turns into a fixed pattern of action through the process of repetition (imitation) done by many people in a relatively long time to form a habit ${ }^{4}$. The pattern of action is adapted as a habit by the individual in relation to the enrichment of the individual experience concerned so that the person has a certain role and is different from the role of the other individual. Therefore, the role of the individual is dependent on how the quality of the individual is able to access with the contribution that gives value to the surrounding environment.

Giyah's socialization as a mask dancer was firstly pioneered by her father since childhood in the hope that she can later become a female player, as it has been widely played by male dancers dressed like women. In the teenage years, Giyah became acquainted with Sartono, a mask dancer from Gunungsari. Their meeting ended in a marriage which then was blessed with four children who all become artists. This love from the first sight is able to support her to become female mask dancer who is reliable and respected by his friends. As an artist and a housewife, Giyah is able to be a role model for her children and society. As a local artist, she is also able to carry the good name of Klaten Regency, both as a puppeteer and as a wayang topeng dalang dancer. The success of the children become dalangs and dancers, certainly can not be separated from the role of Giyah and Sartono as the parents. Exemplary and robustness are both important parts of how cultural inheritance can take place in the family environment. Individuals in the 
community are personal who have integrity that is determined by the cultural structure and social environment in question.

\section{Cultural Enculturation}

Cultural enculturation is a process where an individual learns and adapts his or her mind and attitude to the values, norms, and rules that live in his culture (Koentjaraningrat 1985: 233). The process of culture is individual; the actor has integrity and intellectual that will shape his personality. In the internal environment, individuals are guided by fathers and mothers, as well as close relatives who get along daily. They deliberately or unintentionally mimic what is heard and seen at home, without thinking what is imitated is positive or negative.

In the process of enculturation, the individual has the imitating power as a process of learning towards something called input that is considered beneficial for the development of his personality. The feelings and cultural values that motivate the imitating act are internalized in his personality so that it becomes a steady pattern and the norms that govern his actions are "cultivated". The culture process is accommodative and competitive, in the form of knowledge and skills that have benefits for the individual and community. The acculturation process is used as the values in acting so that the results of internalization are socialized to the community as part of their caring attitude towards the environment.

The process of enculturation in the field of puppetry and wayang topeng dalang is part of Giyah's lifestyle as creative and productive individual; even the profession is cultivated to make living of her family. Having such professions, she is a tolerant person. It is demonstrated by her humble attitude and she always cares about others. The enculturation process also applies to four of her children who work as dalangs and dance artists so that the pattern of the inheritance of traditional art goes and works well. Transmission of knowledge and skills of Giyah and Sartono as a puppeteer is done to their four children.
The process of enculturation in the family environment has significance for the process of its distribution in the community through the activities of wayang kulit and wayang topeng dalang performances.

\section{Giyah's Contribution and Achievement}

For a puppeteer like Giyah, her contribution deals with meeting the customer's requests for a particular interest and distributing honoraria to all the supporters of the show. Behind such contribution, there must be a number of proud achievements associated with hard work, policy, commitment and obedience in the art to the customer, both nationally and internationally. The gained achievements are the evidence of her high quality with high artistic reputation.

The dynamics of Giyah's life history as a traditional art artist cannot be separated from Sartono's role as her husband, and her father is a puppeteer and wayang topeng dalang player. The traditionally-cultural, family-based pattern of cultural inheritance is a strategic factor for the transmission of knowledge and art skills. According to the results of research, a professional is an individual who has emotional intelligence until he is able to overcome the conflict he is facing, including in the establishment of a vision, commitment, and others.

\section{Conclusion}

Giyah is a phenomenal local artist, a dalang and player of wayang topeng dalang of Klaten. She is an active heir of her father named Joko Purwa Handaya and her grandfather named Widhi Harsono. Both are puppeteers and wayang topeng puppeteers in Klaten. The family cultural system in the inheritance of traditional art cause the descendants to gain knowledge and art skills from their parents or ancestors to continue the expertise in the field of traditional art.

The trace of an active heir, Giyah, is a form of self-actualization of the process of internalization, socialization, and enculturation so that she has become a public figure from the family 
of puppeteer and wayang topeng dalang player from Klaten. Giyah is a unique and interesting woman, and is popularly associated with the life of the art world that has successfully raised the predicate of Kadipolo, village where she lives, and the Klaten regency. The family as the center of the inheritance of traditional art is an informal educational institution that is able to shape the individual personality into a qualified artist. Giyah is an example of female artist who becomes a qualified dalang, mask dancer, and wayang topeng dalang player. Her reputation is able to contribute to the society needs and local government.

Giyah's persistence in maintaining the traditional art heritage is a form of dedication to the preservation and development of traditional art as a local wisdom that becomes the pride of Klaten. She is a female character who has become an icon of independence of all-round traditional art artists. Her skills are inherited by her four children who also become dalang and dancer. Giyah's exemplary figure as a housewife and tradition artist is expected to inspire other families so that the art of tradition can continue to be sustainable and developed as the personality (identity) of the nation.

\section{References}

Abdullah, Irwan. (2006). Konstruksi dan Reproduksi Kebudayaan. Yogyakarta:
Pustaka Pelajar.

Haviland, William A. (1985). Antropologi. Jilid ke-2.Terjemahan R.G. Soekadijo. Jakarta: Erlangga.

Ihromi, T.O. Editor. (1986). Pokok-Pokok Antropologi Budaya. Jakarta: Gramedia.

Koentjaraningrat. (1986). Pengantar Ilmu Antropologi. Jakarta: Aksara Baru.

Kuntowijoyo. (2003). Metodologi Sejarah. Edisi ke-2. Yogyakarta: Tiara Wacana.

Poespowardojo, Soerjoanto. (1989). Strategi Kebudayaan, Suatu Pendekatan Filosofi. Jakarta: Gramedia.

Ratna, Nyoman Kutha. (2010). Metodologi Penelitian Kajian Budaya dan Ilmu Sosial Humaniora pada Umumnya. Yogyakarta: Pustaka pelajar.

Rustopo. (2007). “Lembaga Pendidikan Seni dan Pewarisan Seni" dalam Majalah Gong. No. 91/VIII/2007.

Salim, Hairun dan Dhian Hapsari. (2007). "Keluarga dan Pewarisan Seni"dalam Gong, Media, Seni, dan Pendidikan Seni. No. 91/VIII/2007. Yogyakarta: YayasanTikar Media Budaya Nusantara.

Soetarno. (2005).Pertunjukan Wayang dan Makna simbolik. Surakarta: STSI Press.

Suwasono, Bening Tri. (2013)."Rupa Topeng Klaten Koleksi Bambang Suwarno”, dalam Dewa Ruci, 8(3).

Groenendael,Victoria M. Clara. (1987). Dalang di Balik Wayang. Jakarta: Pustaka Utama Grafiti. 


\title{
SUBJECT INDEX
}

\author{
B \\ batik $43,46,83$ \\ E \\ Enthus Susmono 1, 2, 3, 4, 6, 7, 8, 10, 12 \\ Eyes of Marege 36, 37, 38, 39, 42 \\ F \\ female puppeteer 96 \\ G \\ Giyah Supanggah $96,97,98,100,101,102$, \\ 104

\section{I} \\ Indonesian art 43, 48 \\ Iran Constitutional Revolution 59 \\ Iranian drama 59, 60, 62, 64 \\ J \\ Javanese performance 13 \\ Julie Janson $36,37,40$ \\ L \\ Ludruk Karya Budaya 65, 66, 67 \\ M \\ Makasarese folklore 36 \\ Malay dance $50,51,52,54,56,57,58$ \\ mamaca 43,44 \\ maritime culture 50,51 \\ $\mathbf{N}$ \\ NEO Theater $76,77,78$ \\ $\mathbf{P}$ \\ pamenan $22,23,24,25,26,27,28,29,30$, \\ $32,33,34,35$ \\ pamenan Kato 22, 28 \\ pamenan Mato 22, 28, 29 \\ pattern of four $50,51,53,54$ \\ Potehi $13,14,15,16,17,18,19,20$ \\ puppet theater $13,14,15,16,17,19,20$ \\ $\mathbf{R}$ \\ realistic drama $59,61,62,64$ \\ S \\ Sarip Tambak Oso $65,66,67,69,74$ \\ T \\ theater history 76,78 \\ theater production 76 \\ traditional dance 43 \\ W \\ wayang golek Tegal 1 \\ wayang Klithik 84, 85, 86, 87, 88, 89, 90, 91, \\ 92, 93, 94 \\ wayang Padang $22,23,24,25,26,28,29,30$, \\ $31,32,33,34,35$ \\ wayang Pesisiran 1 \\ wayang topeng dalang $96,97,98,100,101$, \\ $102,103,104,105$ \\ Wisran Hadi 22, 23, 24, 25, 29, 30, 31, 33, \\ 34,35 \\ Wonosoco 84, 85, 86, 87, 88, 89, 90, 91, 92, \\ $93,94,95$
}




\section{AUTHOR INDEX}

Abdullah, Tatang 76

Anggara, Alif 36

Dimyati, Ipit Saefidier

76

Hariyanto 1

Hersapandi 96

Kuardhani, Hirwan 13

Kusmayati, A.M. Hermien
Martiara, Rina 50

Murtana, I Nyoman 84

Nazar, Sahrul 22

Wahyuni, Sri Dwi 96

Wardhani, Jihan Kusuma 65

Zahedi, Farindokht 59 